\title{
Kimberlites in The Forrest River Area, Kimberley Region, Western Australia
}

\author{
Wyatt B.A. ${ }^{1}$, Sumpton J.D.H. ${ }^{1}$, Shee S.R. ${ }^{1}$ and Smith T.W. ${ }^{2}$
}

1. Stockdale Prospecting Ltd., P.O. Box 126, South Yarra, Melbourne, VIC 3183, Australia

2. Minorco Services (Singapore), Pte. Ltd., 501 Orchard Rd. Wheelock Place, Singapore 238880.

\section{Introduction}

Diamond exploration commenced in the Northern Kimberley with Tanganyika Holdings/CRA Exploration in 1972, and later included Stockdale Prospecting Ltd. (SPL), and most extensively BHP Minerals, up until 1987. This led to the discovery of six major occurrences, comprising two pipes (Skerring and Pteropus 01) and four dykes. During the period 1990-1994 SPL, in Joint Venture with BHP, undertook extensive exploration within the Forrest River Aboriginal Reserve, primarily using aeromagnetics and heavy mineral sampling. Seventeen kimberlites were identified, most being small, dyke-like bodies. However two pipes, Pteropus 02 and Seppelt 01 (Figure 1), are sizeable with the latter being significantly diamondiferous and of continuing economic interest.

The North Kimberley region lies wholly within the Kimberley Basin, which comprises a series of near flat lying sedimentary and basaltic units accumulated at approximately $1800 \mathrm{Ma}$ on stable continental crust (Jaques et al., 1986). The basement age of the Kimberley Basin is unknown but is inferred to be Archaean.

\section{Discovery of the Seppelt 01 and Pteropus 02 Pipes}

The Seppelt 01 kimberlite was discovered after abundant spinels and diamonds were recovered in drainage samples downstream of the now known location of the pipe. The best result returned 31 diamonds weighing 1.05 carats, and abundant kimberlitic spinels. Investigation of the drainage around the likely cut off sample located kimberlite float, and subsequently an outcropping dyke. A magnetic anomaly in the vicinity of the dyke was also evident, and subsequent drilling delineated Seppelt 01, a kimberlite pipe. The Pteropus 02 kimberlite was discovered after stream sampling returned many kimberlitic spinels immediately upstream of the Pteropus 01 kimberlite. The airborne survey identified a magnetic anomaly, confirmed as kimberlite after drilling.

\section{Geology}

Seppelt 01 intrudes Pentecost Sandstone. The kimberlite forms two lobes, both of which have a complex geology. However, interpretation was made difficult by the extreme weathering of the kimberlite. The first 30 metres of kimberlite have been weathered to kaolinite. Below this depth more readily recognised hypabyssal facies kimberlite is present. The pipe has a core of hypabyssal kimberlite, which grades into kimberlitic breccia and then into country rock (Figure 2). Kimberlitic breccia is more prevalent in the upper part of the pipe, suggesting the addition of collapsed country rock material.

Pteropus 02 is exposed in a valley in the core of an anticline. It intrudes Warton Sandstone and grades from hypabyssal kimberlite, through kimberlitic breccia, to country rock permeated with kimberlite stringers (Figure 3). Unlike Seppelt 01, it has not undergone extreme weathering.

\section{Geophysics}

The airborne and ground magnetic data over Seppelt 01 show a clear positive dipolar anomaly associated with each of the two lobes of the pipe. The measured magnetic susceptibility ( $0.040 \mathrm{SI}$ units) indicates that the body is strongly magnetic compared with many other kimberlites, however the observed magnetic anomaly is greatly reduced by a strong reversely magnetised remanent component, determined by measurements on drill core. The airborne and ground magnetic data over the Pteropus 02 body shows a clear anomaly associated with the pipe. 
Gravity data over Seppelt 01 show residual Bouguer gravity lows over both lobes of the kimberlite, with a maximum amplitude of $0.5 \mathrm{mGal}$. This is considered typical of kimberlites in this environment and is attributed to weathering at the top of the pipe. A residual low of $1.6 \mathrm{mGal}$ is associated with Pteropus 02. A smaller low, $0.6 \mathrm{mGal}$ in amplitude is coincident with the Pteropus 01 breccia, which is not resolvable from the magnetic data. The gravity response of the Pteropus 02 pipe infers a larger body than would be interpreted from the magnetic data. The magnetic response is probably due to the magnetic, hypabyssal core of the intrusion, while the gravity response has a significant contribution from brecciated country rock surrounding the central core. The form of the gravity map is somewhat disturbed by a steep topographic slope to the west of Pteropus 01.

The Dighem helicopter EM system was flown over Seppelt 01. The response is interpreted as a weak conductor associated with the top, weathered portion of the pipe. SIROTEM Mk III and Geonics EM-34 data were acquired over the body. The clearer response is from the latter.

\section{Mineral Chemistry}

Pteropus 02 contains chrome spinel, garnets, rare ilmenites, and clinopyroxene. The garnets are lherzolitic, and no true sub-calcic varieties were found. The Pteropus 02 spinels (Figure 4) are generally typical kimberltic varities, but a distinctive low-MgO (less than 8.0 wt. \%) high- $\mathrm{TiO}_{2}$ (more than $2.0 \mathrm{wt}$. \%) population is also present.

Seppelt 01 contains large numbers of chrome spinel, rare garnets located only at depth, and no ilmenites. A typical suite of high-MgO kimberlitic spinels is present which includes many high $\mathrm{TiO}_{2}$ grains. The garnets are dominated by lherzolitic and Ca-harzburgitic varities including some subcalcic garnets (Figure 5).

Proton probe trace element analyses of selected Seppelt 01 and Pteropus 02 garnets show that many are depleted (less than about $10 \mathrm{ppm} \mathrm{Y}$ and $50 \mathrm{ppm} \mathrm{Zr}$ ), but some grains are enriched in $\mathrm{Zr}$ in particular (up to about $150 \mathrm{ppm}$ ). A Ni/Cr geotherm calculated using the methods outlined by Griffin and Ryan (1995) and Ryan et al. (1996) suggest normal cratonic gradients of close to 40 $\mathrm{mW} / \mathrm{m}^{2}$ for the area (Figure 6) at the time of pipe emplacement. A Rb/Sr phlogopite model age of $784 \mathrm{Ma}$ is given by Barton and Smith (De Beers internal report, 1992) for Seppelt 01(consistent with about $800 \mathrm{Ma}$ by association with the Skerring and Pteropus 01 kimberlites - see Jaques et al., 1986). A ${ }^{40} \mathrm{Ar} /{ }^{39} \mathrm{Ar}$ phlogopite date of about $860 \mathrm{Ma}$ has been obtained for Pteropus 02 by Phillips (De Beers internal report, 1994).

\section{References}

Griffin, W.L. and Ryan, C.G. 1995, Trace elements in indicator minerals: area selection and target evaluation in diamond exploration: J. Geochem. Explor.,53, p. 311-337.

Gurney, J.J., 1984, A correlation between garnets and diamonds. In: J.E. Glover and P.G. Harris (Eds.), Kimberlite Occurrence and Origins, a Basis for Conceptual Models in Exploration: Geol Dept. and Univ. Ext., Univ. of West. Aust. Publ. No. 8, p143-166.

Jaques, A.L., Lewis, J.D. and Smith, C.B., 1986, The Kimberlites and Lamproites of Western Australia: Geol. Surv. West. Aust. Bull. 132.

Ryan, C.G., Griffin, W. L., and Pearson N. J., 1996, Garnet geotherms: pressure-temperature data from Cr-pyrope garnet xenocrysts in volcanic rocks: J. Geoph. Res., 101(B3) p. 5611-5625.

Sobolev, N.V., Lavrentlev, Yu G.,Pokhilenko, N.P. and Usoval V., 1973, Chrome-rich garnets from the kimberlites of Yakutia and their parageneses: Contrib. Mineral. Petrol., 400, 39-52. 


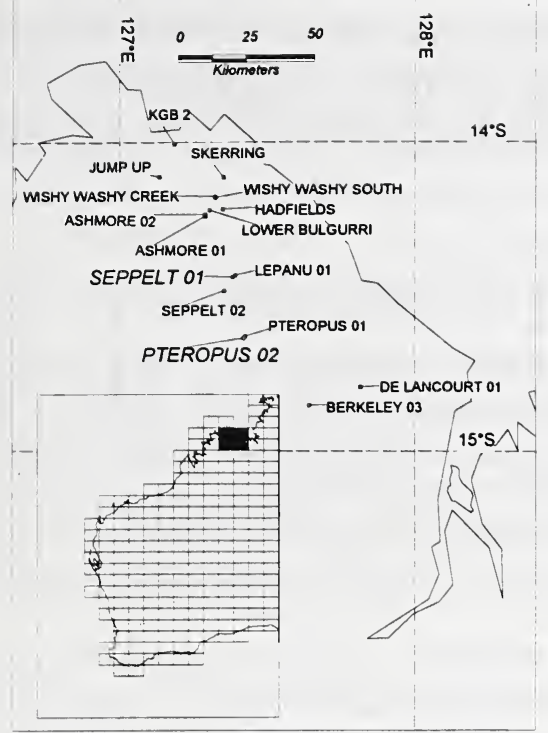

Figure 1

Geological Plan of Pteropus 02 Kimberlite

$\underbrace{0.50 \quad 100 \quad 150 m}$ $.4^{\circ}$ KMegrime breccia

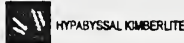
- 0 xagerutte stracers

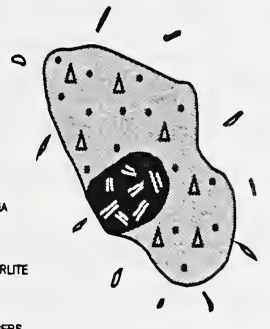

Figure 3

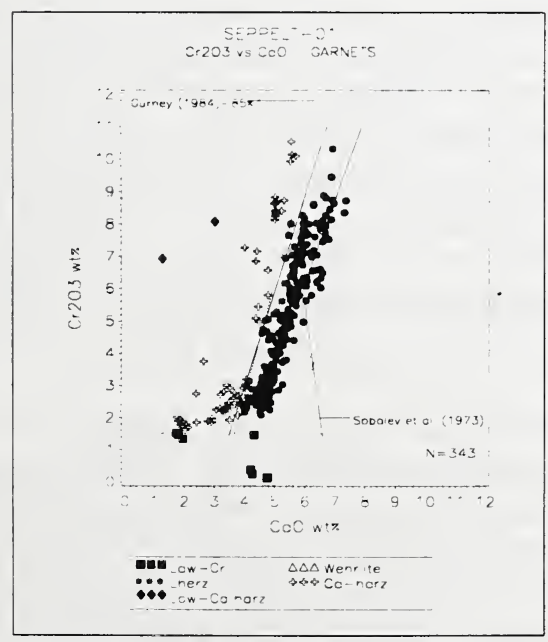

Figure 5

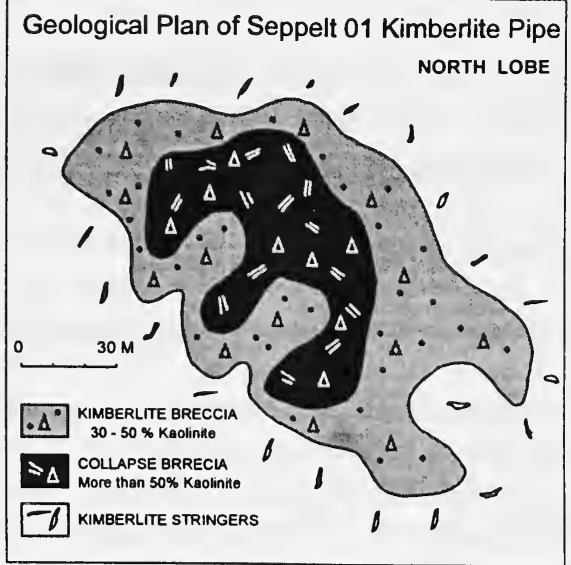

Figure 2

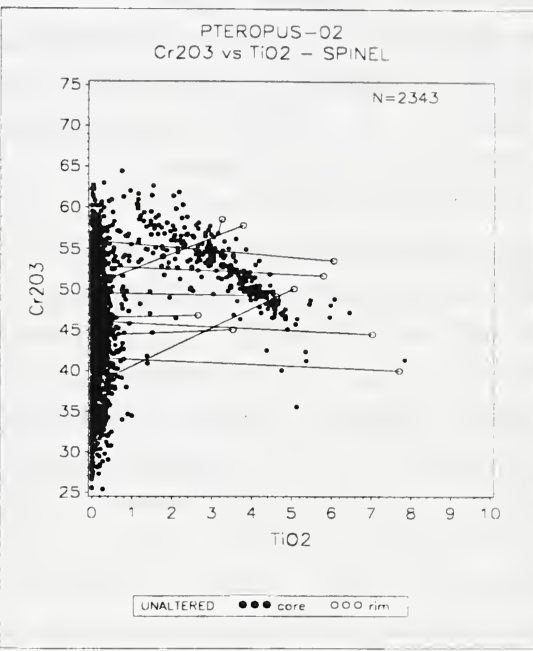

Figure 4

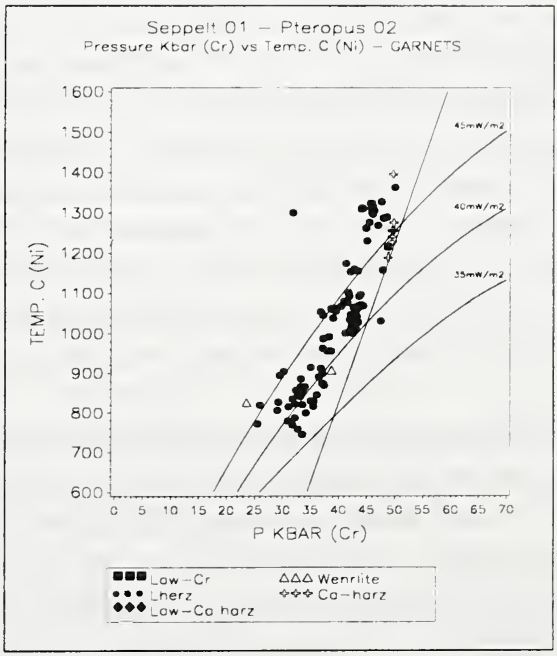

Figure 6 